Macmillan Computer Science Series

Consulting Editor:

Professor F.H. Sumner, University of Manchester

A. Abdellatif, J. Le Bihan, M. Limame, Oracle - A User's Guide

I. O. Angell, High-resolution Computer Graphics Using $C$

I. O. Angell and G. Griffith, High-resolution Computer Graphics Using FORTRAN 77

I. O. Angell and G. Griffith, High-resolution Computer Graphics Using Pascal

C. Bamford and P. Curran, Data Structures, Files and Databases, second edition

P. Beynon-Davies, Database Systems

P. Beynon-Davies, Information Systems Development, second edition

G.M. Birtwistle, Discrete Event Modelling on Simula

Linda E.M. Brackenbury, Design of VLSI Systems - A Practical Introduction

Alan Bradley, Peripherals for Computer Systems

G.R. Brookes and A.J. Stewart, Introduction to occam2 on the Transputer

P.C. Capon and P.J. Jinks, Compiler Engineering Using Pascal

B. S. Chalk, Computer Organisation and Architecture - An Introduction

Robert Cole, Computer Communications, second edition

Eric Davalo and Patrick Naïm, Neural Networks

S.M. Deen, Principles and Practice of Database Systems

Joyce Duncan, Lesley Rackley and Alexandria Walker, SSADM in Practice

D. England et al., A Sun User's Guide, second edition

Jean Ettinger, Programming in $C++$

J.S. Florentin, Microprogrammed Systems Design

A.B. Fontaine and F. Barrand, 80286 and 90386 Microprocessors

Michel Gauthier, Ada - A Professional Course

M.G. Hartley, M. Healey and P.G. Depledge, Mini and Microcomputer Systems

J.A. Hewitt and R.J. Frank, Software Engineering in Modula-2

- An Object-oriented Approach

Patrick Jaulent. The 68000 - Hardware and Software

M.J. King and J.P. Pardoe, Program Design Using JSP - A Practical Introduction, second edition

Bernard Leguy, Ada - A Programmer's Introduction

M. Léonard, Database Design Theory

David Lightfoot, Formal Specification Using $Z$

A.M. Lister and R.D. Eager, Fundamentals of Operating Systems, fifth edition

Elizabeth Lynch, Understanding $S Q L$

Tom Manns and Michael Coleman, Software Quality Assurance, second edition

G.P. McKeown and V.J. Rayward-Smith, Mathematical Foundations for Computing

B.A.E. Meekings, T.P. Kudrycki and M.D. Soren, $A$ book on $C$, third edition

R.J. Mitchell, $C++$ Object-oriented Programming

R.J. Mitchell, Microcomputer Systems Using the STE Bus

R.J. Mitchell, Modula-2 Applied

Ian Pratt, Artificial Intelligence

Pham Thu Quang and C. Chartier-Kastler, MERISE in Practice

E.J. Redfern, Introduction to Pascal for Computational Mathematics

continued overleaf 
F.D. Rolland, Programming with VDM

A.G. Sutcliffe, Human-Computer Interface Design, second edition

C.J. Theaker and G.R. Brookes, Concepts of Operating Systems

M. Thorin, Real-time Transaction Processing

A.J. Tyrell, Eiffel Object-Oriented Programming

Other titles

Ian O. Angell and Dimitrios Tsoubelis, Advanced Graphics on VGA and XGA Cards

Using Borland $\mathrm{C}++$

N. Frude, $A$ Guide to SPSS/PC+, second edition

Peter Grossman, Discrete Mathematics for Computing

H. Harper and A. Meadows, GNVQ Advanced Information Technology

Percy Mett, Introduction to Computing

P.D. Picton, Neural Networks

Tony Royce, $C O B O L$ - An Introduction

Tony Royce, Structured COBOL - An Introduction

Tony Royce, $C$ Programming 


\section{Computer Organisation and Architecture}

\section{An Introduction}

\section{B.S. Chalk}

School of Computing Information Systems and Mathematics South Bank University, London

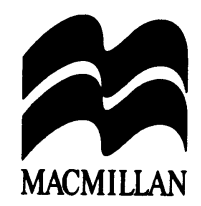




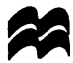

(c) B. S. Chalk 1996

All rights reserved. No reproduction, copy or transmission of this publication may be made without written permission.

No paragraph of this publication may be reproduced, copied or transmitted save with written permission or in accordance with the provisions of the Copyright, Designs and Patents Act 1988, or under the terms of any licence permitting limited copying issued by the Copyright Licensing Agency, 90 Tottenham Court Road, London WIP 9HE.

Any person who does any unauthorised act in relation to this publication may be liable to criminal prosecution and civil claims for damages.

First published 1996 by MACMILLAN PRESS LTD

Houndmills, Basingstoke, Hampshire RG21 6XS

and London

Companies and representatives

throughout the world

ISBN 978-0-333-64551-2 ISBN 978-1-349-13871-5 (eBook)

DOI 10.1007/978-1-349-13871-5

A catalogue record for this book is available from the British Library.

$\begin{array}{llllllllll}10 & 9 & 8 & 7 & 6 & 5 & 4 & 3 & 2 & 1\end{array}$

$\begin{array}{llllllllll}05 & 04 & 03 & 02 & 01 & 00 & 99 & 98 & 97 & 96\end{array}$ 


\section{Contents}

Preface

viii

Acknowledgements

1 Introduction

1.1 The von Neumann Computer Model

1.2 A Microcomputer System

1.3 Representing Memory

1.4 High and Low-Level Languages

1.5 The Operating System

1.6 Answers to Text Questions

1.7 Exercises

2 Digital Logic Circuits $\quad 8$

2.1 Logic Gates $\quad 8$

2.2 Combinational Logic Circuits 10

2.3 Sequential Logic Circuits 13

2.4 D-type Flip-Flop Circuits 17

2.5 Answers to Text Questions 21

2.6 Exercises 22

3 Data Representation and Computer Arithmetic 23

3.1 Bits, Bytes and Words 23

3.2 Binary Codes 24

3.3 Number Systems 25

3.4 Negative Numbers 28

3.5 Binary Arithmetic 30

3.6 Binary Coded Decimal (BCD) 34

3.7 Floating Point Representation 34

$\begin{array}{lll}3.8 & \text { Summary } & 37\end{array}$

3.9 Answers to Text Questions 38

3.10 Exercises $\quad 39$ 
$4 \quad$ Fetching and Executing Instructions 40

4.1 Processor-Memory Interconnection $\quad 40$

4.2 Fetching Instructions 41

4.3 Instruction Format 46

4.4 Executing Instructions $\quad 48$

$\begin{array}{lll}4.5 & \text { Summary } & 52\end{array}$

4.6 Answers to Text Questions 53

$\begin{array}{lll}4.7 & \text { Exercises } & 53\end{array}$

5 The Motorola MC68000 55

5.1 Programmer's Model of the $68000 \quad 55$

$\begin{array}{lll}5.2 & \text { Instruction Types } & 60\end{array}$

5.3 Addressing Modes 64

$\begin{array}{lll}5.4 & \text { Instruction Formats } & 70\end{array}$

5.5 Assembly Code Examples $\quad 72$

$\begin{array}{lll}5.6 & \text { Supervisor Mode } & 78\end{array}$

$\begin{array}{lll}5.7 & \text { Trace Mode } & 79\end{array}$

$\begin{array}{lll}5.8 & \text { Summary } & 79\end{array}$

5.9 Answers to Text Questions $\quad 80$

$\begin{array}{lll}5.10 & \text { Exercises } & 81\end{array}$

6 Computer Memory 83

$\begin{array}{lll}6.1 & \text { Memory Hierarchy } & 83\end{array}$

$\begin{array}{lll}6.2 & \text { Semiconductor Technology } & 84\end{array}$

6.3 Semiconductor Memory Chips 88

$\begin{array}{lll}6.4 & \text { Processor-Memory Bus } & 95\end{array}$

6.5 Cache Memory 98

6.6 Secondary Memory 105

$\begin{array}{lll}6.7 & \text { Summary } & 115\end{array}$

6.8 Answers to Text Questions 115

$\begin{array}{lll}6.9 \text { Exercises } & 116\end{array}$

7 Input-Output 118

$\begin{array}{lll}7.1 & \text { Types of Interface } & 118\end{array}$

$\begin{array}{lll}7.2 & \text { Parallel IO } & 119\end{array}$

$\begin{array}{lll}7.3 & \text { Serial IO } & 122\end{array}$

$\begin{array}{lll}7.4 & \text { IO addressing } & 127\end{array}$

$\begin{array}{lll}7.5 & \text { Modes of IO Transfer } & 128\end{array}$

$\begin{array}{lll}7.6 & \text { Summary } & 134\end{array}$

7.7 Answers to Text Questions 135

$\begin{array}{lll}7.8 & \text { Exercises } & 136\end{array}$ 


\section{Contents}

vii

8 Operating Systems 137

$\begin{array}{lll}8.1 \text { Overview } & 137\end{array}$

8.2 Multiprogramming 138

8.3 The Process Concept 139

$\begin{array}{lll}8.4 & \text { Process Management } & 140\end{array}$

8.5 Process Scheduling 142

8.6 Inter-Process Communication 143

8.7 Memory Management 147

$\begin{array}{lll}8.8 & \text { Summary } & 153\end{array}$

8.9 Answers to Text Questions 154

8.10 Exercises 155

9 Reduced Instruction Set Computers 156

9.1 CISC Characteristics 156

9.2 Instruction Usage 157

9.3 RISC Architectures 158

9.4 The Control Unit 163

$\begin{array}{lll}9.5 & \text { Pipelining } & 167\end{array}$

9.6 Microprocessor Performance 176

9.7 Superscalar and Superpipelined Architectures 177

$\begin{array}{lll}9.8 & \text { Summary } & 178\end{array}$

9.9 Answers to Text Questions 178

$\begin{array}{lll}9.10 \text { Exercises } & 179\end{array}$

10 Parallel Architectures 181

10.1 Classifying Parallel Architectures 181

10.2 SIMD Array Processors 183

10.3 Dataflow Computers 184

10.4 MIMD Systems 186

10.5 Amdahl's Law 196

10.6 Summary 198

10.7 Answers to Text Questions 198

$\begin{array}{lll}10.8 & \text { Exercises } & 199\end{array}$

Appendices

1 ASCII Table 201

2 Answers to Exercises 202

$\begin{array}{ll}\text { Index } & 207\end{array}$

$\begin{array}{ll}\text { Acronyms } & 213\end{array}$ 


\section{Preface}

A computer is a versatile machine, capable of performing a wide range of tasks. At the heart of the machine lies a primitive language processor, which is interconnected with other functional units to provide a hardware platform for running programs. Computer organisation is a term used to describe the operation and interconnection of these functional units while computer architecture describes how the hardware platform appears to a machine language programmer.

The aim of this book is to provide a sufficiently detailed coverage of computer organisation and architecture to meet the needs of students on first year degree and HND courses in Computer Studies, Information Technology, Software Engineering and related areas of study. The material is also suitable for students taking conversion courses in areas such as Advanced Information Technology, Computer Science or for anyone wishing to gain a basic understanding of how a computer works. Apart from a rudimentary understanding of high-level language programming, no other prior level of knowledge is assumed.

The book adopts an interactive approach and supports self-study, by including an extensive number of Text Questions (TQs) for self-assessment purposes. Answers to TQs are given at the end of each chapter, together with a set of further exercises. Selected answers to these exercises are given at the back of the book.

Because of its widespread use as a teaching tool, I have adopted the Motorola 68000 as a vehicle for explaining the principles of processor operation and assembly language programming. Readers familiar with Intel or other processors should have no difficulty in adapting the concepts and program examples to other machines.

The book is divided into ten chapters. Chapters 1 to 7 include the basic core material we use at South Bank University for teaching one semester units in Computer Systems Architecture, Computer and Communication Architecture and Computer Systems Technology. Chapter 8, which provides an introduction to operating systems, is included to bridge the gap between Computer Architecture and System Software - a unit normally undertaken shortly afterwards. Chapters 9 and 10 introduce the more advanced topics of RISC and Parallel architectures. These topics have been included to illustrate the current trend in architectural development and to provide a foundation for second level units in subjects such as Microprocessor Technology and Concurrent Systems.

B.S. Chalk 


\section{Acknowledgements}

I would like to begin by thanking Dr Mike Oatey for the many suggestions he made during the planning stage of this book. I would also like to thank: Terry Roberts, Ian Marshall and other students for giving me useful feedback on the text questions; Graham Davies, Bob Hine, Pirooz Saeedi and John Hill for their assistance in developing this material over the years; Audrey Curnock for her advice on presentation; Professor Frank Sumner for his comments and suggestions; and Malcolm Stewart from Macmillan Press, for steering the book through its various stages. Last but not least, I would like to thank my wife Anne for her encouragement and support.

London, March 1996 